\title{
JUST HOW MANY OBSTACLES ARE THERE TO CREATING A NATIONAL PARK? A CASE STUDY FROM THE ŠUMAVA NATIONAL PARK
}

\author{
ZDENKA KŘENOVÁ ${ }^{1,2,3, *}$ and JAROSLAV VRBA ${ }^{1}$ \\ ${ }^{1}$ Faculty of Science, University of South Bohemia, Branišovská 31, 37005 České Budějovice, Czech Republic \\ ${ }^{2}$ Global Change Research Centre AS CR, Department of Biodiversity Research, Na Sádkách 7, 37005 České Budějovice, \\ Czech Republic \\ ${ }^{3}$ Institute for Environmental Studies, Faculty of Science, Charles University in Prague, Benátská 2, 12801 Prague 2, \\ Czech Republic \\ *Corresponding author: krenova.z@czechglobe.cz
}

\begin{abstract}
This case study reports the recent history and evaluates the socio-economic constraints on nature conservation in the Bohemian Forest which is the largest natural wilderness area in the central European cultural landscape. This gradually occurred over the past half of century, when nature was allowed to reclaim the most valuable parts along the common Czech-German border and the national parks (NP) were established: the Bavarian Forest NP in Germany (in 1970) and the Šumava NP in the Czech Republic (1991). Unfortunately, since the very beginning of the Šumava NP, its status has been questioned, compromised or debated, and it never received clear political support. Discussions about its future have become never-ending and were only on the appropriate management of the forests, i.e. "non-intervention" management versus "necessary" bark-beetle control. The "bark beetle problem", however, is a wildcard issue that has obscured much more complex problems. This paper is the first attempt to describe the main obstacles and offer some solutions for making the Šumava NP a successful and sustainable project.
\end{abstract}

Keywords: national park, protected area management, socio-economic development

\section{Introduction}

For historical reasons, a mountain range along the Czech-German border, the Bohemian Forest, has become the largest natural wilderness area in the central European cultural landscape. This gradually occurred over the past half of century, as the most valuable parts of the Bohemian Forest were eventually incorporated into a national park (NP) - Fig. 1. The Bavarian Forest National Park was declared as the first German NP in 1970 and greatly extended in 1997 to the present area of 24,218 ha. The neighbouring Šumava Protected Landscape Area (PLA) on the Czech side (total area of 167,688 ha) was established in 1963. The Šumava National Park (68,064 ha) was established in 1991. More than two decades after the collapse of the "Iron Curtain", however, effective trans-boundary cooperation and nature protection in the Bohemian Forest remains an unfulfilled aspiration. What has gone wrong, particularly on the Czech side?

Since the very beginning of the Šumava NP decisions about its management have been bogged down in never-ending discussions about whether bark beetle infestations should be controlled or a strict "non-intervention" policy adopted. In our experience, the "bark beetle" problem is a wildcard issue and there are much more serious problems. This paper is the first attempt to describe the main obstacles to agreeing a management policy and offer some solutions for making the Šmava NP a successful and sustainable project.

\section{Historical Background}

Numerous opponents of wild nature in the Šumava NP used to argue that the Bohemian Forest in the past was a densely populated cultural landscape in which the Norway spruce forests had been managed for centuries. This ignores the fact that the Bohemian Forest was colonized quite late and the settlements only had local effects on the forest until the last 150 years. Formerly the people simply had no reason, time, tools or vehicles for exploiting the upland landscape. In addition, following the peak in population there in the second half of the 19th century it declined due to a gradual impoverishment of these marginal settlements up to the outbreak of World War II. After 1945, most of the original residents were displaced from the Czech part of the Bohemian Forest and many villages in the frontier area were abandoned, often even intentionally destroyed. Some of the other villages were resettled with newcomers that had no experience of living in a mountainous region, were vetted and subsidized to live in this frontier zone during the socialist era. The number of residents more or less remained the same between 1950 and 1990 (Perlín and Bičík 2010). Before the establishment of the Šumava NP the local economy was based mainly on extensive forestry and agriculture, whereas tourism suffered because the area consisted of both a frontier zone and closed military training areas.

Although Czech scholars had limited access to the Bohemian Forest, which remained largely unexplored 


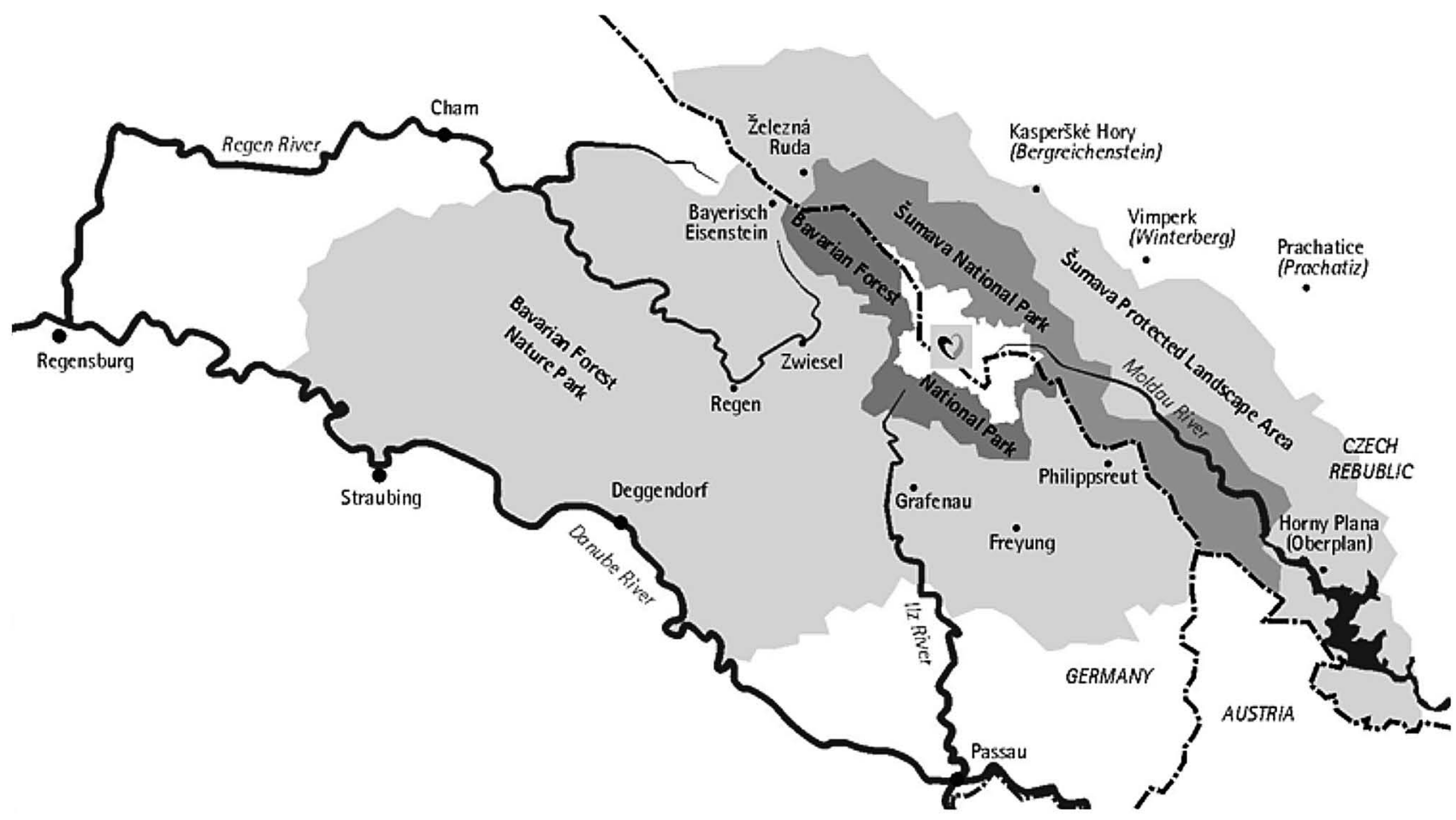

Fig. 1 Map showing the locations of the Šumava National Park in the Czech Republic and the Bavarian Forest National Park in Germany (with a common trans-boundary area of proposed Europe's Wild Heart in white). Other protected areas in the trans-boundary region are also shown in light gray.

until the 1990s, they were aware it contained many rare organisms and suggested the establishment of the Šmava PLA already in 1963. At that time, there was no political desire for establishing the Šumava NP. Some of the endangered species that occurred in refugia along the "Iron Curtain" were threatened by extensive forestry, whereas nature reclaimed abandoned settlements and specific disturbance regimes prevented succession in secondary grasslands in the military training areas (Prach et al. 1996, 2000). Moreover, current research on several Norway spruce stands along the frontier range has clearly confirmed that natural old-growth forests are more common at high altitudes in the Bohemian Forest than previously thought (e.g. Svoboda 2005, 2007; Janda et al. 2010; Hubený and Čížková 2013). Thus, the establishment of the Šumava NP in 1991 was a good solution for this marginal region of great natural value. At the same time, in 1990, the former Šumava PLA was included in the list of UNESCO Biosphere Reserves (BR) and the Šumava peatlands became an important Ramsar site. In 2005, the whole of the Šumava NP became a Natura 2000 protected area, both under the SPA (the Birds EU Directive) and SAC (the Habitats EU Directive). As bilateral cooperation between the Bavarian Forest NP and Šumava NP Authorities largely improved during the 2000s, the first trans-boundary central European wilderness area of international importance, Europe's Wild Heart, was proposed for the adjacent core zones of the two NPs in 2008 (Meyer et al. 2009; Křenová and Kiener 2012; see Fig. 1).

\section{Zonation}

The Šumava NP was established in the most valuable, central and parts along the border of the Šumava PLA, whose remaining area $(99,624 \mathrm{ha})$ became a buffer zone of the NP (Fig. 1). Unlike many other national parks, including the Bavarian Forest NP, municipalities and their lands are parts of the Šumava NP. There is currently less than 1,000 permanent residents living in six villages located inside the Šumava NP and land administered by sixteen municipalities partly overlap the Šumava NP (Table 1). The original concept assumed that nature would be strictly protected in the NP, with the area with the highest conservation value and least affected by humans, partly adjacent to the Bavarian Forest NP. Development was to be more strictly regulated in the large core zones of the Šumava NP than in the buffer area of the Šumava PLA, where a mixture of development and conservation was welcomed, particularly in the villages neglected for decades, but was implemented only in the initial years of the Šumava NP.

Article 4 of the Czech Government Regulation No. 163/1991 of March 20, 1991, which established the Šmava NP and set the conditions for its protection, says: "methods and ways of protecting the national park are differentiated according to the distribution of the national park into three zones defined according to their natural values." Areas with the most important natural values in the national park should be classified as Zone I (strictly natural), particularly natural or slightly amended ecosys- 
Table 1 Alphabetical list of the municipalities, their administrative territories (AT), its percentage of the Šumava NP (\% of AT in NP; those with 100\% are in bold) and of the total area (\% of NP area), number of permanent inhabitants, percentage unemployment (UER), percentages of graduate residents ( $\mathrm{M}$ - males, $\mathrm{F}$ - females) and their specific incomes (annual means for 2008-2012 were used to avoid extremes).

\begin{tabular}{|c|c|c|c|c|c|c|c|c|}
\hline Municipality & $\begin{array}{c}\text { AT } \\
\text { (ha) }\end{array}$ & $\begin{array}{c}\text { AT in NP } \\
(\%)\end{array}$ & $\begin{array}{l}\text { NP area } \\
(\%)\end{array}$ & Inhabitants* & $\begin{array}{l}\text { UER }^{*} \\
(\%)\end{array}$ & $\begin{array}{c}\text { Graduates* } \\
\text { M (\%) }\end{array}$ & $\begin{array}{c}\text { Graduates* } \\
\text { F (\%) }\end{array}$ & $\begin{array}{c}\text { Incomes } \\
\text { (CZK/resident) }\end{array}$ \\
\hline Borová Lada & 6,895 & 48 & 4.86 & 280 & 12.3 & 5.0 & 3.6 & 43,420 \\
\hline Čachrov & 8,818 & 19 & 2.45 & 553 & 11.4 & 4.6 & 5.2 & 38,225 \\
\hline Hartmanice & 6,221 & 27 & 2.51 & 1,106 & 15.4 & 4.4 & 3.3 & 31,874 \\
\hline Horní Planá & 9,926 & 15 & 2.20 & 2,189 & 14.0 & 6.1 & 3.7 & 25,486 \\
\hline Horní Vltavice & 5,880 & 8 & 0.68 & 390 & 8.1 & 5.5 & 2.6 & 33,862 \\
\hline Horská Kvilda & 2,991 & 100 & 4.39 & 73 & 5.0 & 6.7 & 20.0 & 50,267 \\
\hline Kašperské Hory & 4,412 & 33 & 2.13 & 1,593 & 15.4 & 7.4 & 5.8 & 53,009 \\
\hline Kvilda & 4,518 & 100 & 6.64 & 170 & 3.0 & 6.7 & 3.9 & 86,603 \\
\hline Lenora & 1,780 & 4 & 0.12 & 800 & 11.5 & 2.8 & 3.3 & 19,631 \\
\hline Modrava & 8,163 & 100 & 11.99 & 52 & 7.4 & 4.3 & 0.0 & 2980,407 \\
\hline Nicov & 1,378 & 11 & 0.22 & 77 & 2.4 & 0.0 & 2.8 & 33,681 \\
\hline Nová Pec & 6,638 & 78 & 7.61 & 563 & 15.8 & 2.1 & 3.6 & 28,811 \\
\hline Nové Hutě & 2,324 & 53 & 1.82 & 85 & 14.6 & 12.5 & 5.0 & 32,270 \\
\hline Prášily & 11,227 & 100 & 16.49 & 152 & 23.2 & 12.0 & 5.3 & 67,023 \\
\hline Rejštejn & 3,044 & 84 & 3.76 & 236 & 22.6 & 4.5 & 0.8 & 47,833 \\
\hline Srní & 3,348 & 100 & 4.92 & 290 & 9.2 & 3.5 & 4.2 & 65,891 \\
\hline Stachy & 2,813 & 8 & 0.32 & 1,218 & 6.2 & 7.2 & 5.3 & 19,620 \\
\hline Stožec & 10,478 & 100 & 15.39 & 212 & 9.7 & 11.2 & 3.8 & 69,278 \\
\hline Strážný & 4,964 & 92 & 6.71 & 451 & 10.7 & 6.0 & 3.6 & 81,756 \\
\hline Volary & 10,763 & 11 & 1.79 & 4,013 & 9.0 & 4.9 & 2.9 & 20,548 \\
\hline Želnava & 1,034 & 65 & 0.99 & 139 & 29.0 & 5.4 & 1.9 & 17,753 \\
\hline Železná Ruda & 7,981 & 17 & 2.01 & 2,318 & 7.6 & 7.1 & 5.3 & 23,069 \\
\hline Total / Mean & 125,596 & & 100.00 & 16,960 & 12.0 & 5.9 & 4.4 & $175,924 / 42,377^{* *}$ \\
\hline Pilsen region & & & & 571,709 & 7.0 & & & $\begin{array}{l}20,109^{* * *} \\
12,550^{* * * *}\end{array}$ \\
\hline $\begin{array}{l}\text { South Bohemian } \\
\text { region }\end{array}$ & & & & 636,138 & 7.5 & & & $\begin{array}{l}21,956^{* * *} \\
16,668^{* * * *}\end{array}$ \\
\hline Czech Republic & & & & $10,505,445$ & 8.6 & 10.8 & 7.1 & \\
\hline
\end{tabular}

* at 31/12/2011; ${ }^{* *}$ including/excluding Modrava; ${ }^{* * *} / * * * *$ municipalities with $1-100 / 200-500$ permanent residents, respectively

tems. The aim is to preserve or restore natural ecosystem processes and limit human intervention in the natural environment to maintain this state. Zone II includes the natural areas that in the past were variously influenced by human activities, which now generally require active management, and Zone III includes urban villages and adjacent non-forested areas, where the main habitats are heavily modified and altered by human activities.

The original zonation of the Šumava NP was mostly based on the international concept of zoning as a basic tool for scaling the value and protecting the interior of the NP. But in 1995 the zonation was changed, strictly protected core zones (Zone I) were significantly reduced in area and fragmented (Křenová and Hruška 2012), which was strongly criticized by experts, representatives of international organizations (IUCN, Ramsar Committee) and NGOs. During 2004-2005, the Šumava NP Authority proposed a new zonation, which included the im- portant recommendations of experts. Unfortunately, this proposal was not officially approved, because of opposition from local communities and regional politicians.

\section{Šumava NP and Local Representatives}

The history of the Šumava NP over the last two decades reveals several reasons why international (IUCN) standards were not successfully implemented. The above mentioned problems are remarkable examples of the malfunctioning of the council of the Šumava NP, a consultative and initiative body according to the Act 114/1992 (on nature and landscape protection), and the ambiguous attitudes of the Czech Ministry of Environment.

Experience of the endless negotiations about the new zonation proposal and several other important documents (e.g. new management plan or regulation of vis- 
itors) has shown that local representatives often do not present reasoned arguments and objections but make obstinate claims and dictates. Local representatives very often changed their opinion, thus there was until recently an increasing lack of mutual trust between them and the NP Authority.

First, unlike the Bavarian Forest NP in Germany, the Sumava NP never received full political support from the Czech government. This is well illustrated by the fact that there have been ten directors over a period of 23 years! In contrast, there have been three directors of the Bavarian Forest NP over the 43 years of its history. Thus the position of the Czech directors is likely to have been untenable. In consequence, both the vision and longterm strategy for the Šumava NP remain uncertain and unclear, whereas its budget has largely depended on the sale of timber.

Second, the legal framework that resulted in the establishment of the Sumava NP has been questioned. It was declared by the Czech government prior to the Act 114/1992, which proposed a new national park be established. Though this Act explicitly specified all the then existing national parks, many politicians have frequently abused the situation. Two more serious problems developed before the turn of the century. After heavy lobbying by private owners and foresters, the Czech Parliament approved direct restitution of all the former municipal forests in national parks, which resulted in the Šmava NP losing control over $9.2 \%$ of its area (Šumava NP Authority 2013) and although the owners were eligible for financial compensation for bark beetle damage they became ever more vocal about the "unjust bark beetle control" in surrounding NP forests. The largest parts, including some core zones and long-term reserves, are owned by Kašperské Hory (4,916 ha) and Volary (971 ha). Unfortunately, they manage their forests in a way that does not conform to nature conservation standards. Currently they are arguing that their forests should not be included in the NP. In addition, regional governments were made responsible and given control over the regions established in 2000. Though the Sumava NP clearly came under the jurisdiction of the Ministry of the Environment, both of these regional governments infringed the forestry, nature conservation, regional development, and other rights of the NP. In spite of many other developing and administrative challenges in the South Bohemian region, the region's politicians, encouraged by developers, proposed building a ski lift and ski slope in the core zone of the Sumava NP and commercial canoeing in a unique pearl mussels habitat.

Third, the Šumava NP and PLA Authority and representatives of local municipalities are unreliable partners. Since the very beginning, the Authority continued its rather restrictive approach to nature conservation, often neglecting and ignoring problems and expectations of local people, who largely trusted state paternalism in the past. It took a decade or so, for the Authority to gradually change its approach. Thus, as a consequence, most of the local representatives were unprepared for the new situation in the 1990's, i.e. the political and social changes in the country, opening of the state border, closing of military training areas, and establishment of the Šumava NP, which resulted in the popular saying: "we would like to do this and that, but we cannot because of the NP".

Because of the above the Sumava NP Council has been unable to get the local representatives to cooperate responsibly with the NP Authority. Mayors of 22 municipalities that are within the NP (Table 1), together with representatives of two regions and the mountain rescue service are mandatory members of the Council. These 25 members make up a majority on the Council. The Council is responsible for producing strategic documents on zonation, management and regulation of visitors for the national park. Instead of approving knowledge- and science-based proposals for conserving nature and sustaining biodiversity, the Council acts like a "board of regional regents" without any accountability. Some fulltime mayors often act, more or less deliberately, as latent lobbyist of entrepreneurs, developers or land owners. Some Council's meetings were taken up with only criticising the NP directors, or for formal approval of documents fulfilling the wishes of regional politicians and developers. Three years ago the number of scientists that could complain about these practices was reduced by the political director in order to maintain the majority on the Council. The structure of the obligatory Council favours these hidden interests and often overrules actual nature conservation in the Šumava NP if the director is unable to convince the council otherwise.

Last but not least, during the entire history of the Sumava NP, the Authority has largely focused on an agenda for the NP in terms of forestry and pest control, zonation and the regulation of visitors. Curiously, the Authority has hardly considered the role of the PLA as a buffer zone for the NP. For instance, the management plans of the NP and PLA are largely incompatible, sometimes with contradictory measures being applied in similar habitats and are never synchronised. Similarly, the Authority does not apply the status of the Šumava BR on the NP and PLA territories. An obvious reason is that the $\mathrm{BR}$ has no legal basis in terms of national legislation and, thus, no financial or personal support from the Ministry of Environment or Czech government. In our opinion, the UNESCO BR concept is a good basis for resolving the most controversial issues and an excellent tool for developing a plan for sustainable tourism and the overall development of the entire region. As a matter of fact, the existence of the Šumava NP has increased the potential earnings from tourism not only of the six villages located within the NP and others around the periphery of the NP but also of the many other municipalities in the Bohemian Forest region. The Šumava NP and PLA Authority, however, have not even attempted to implement the UNESCO BR concept in the region over the past 23 years. 


\section{Regional Development and Landscape Planning}

Due to lack of local capital, both privatization and further development of infrastructure for tourism was from the early 1990s largely funded and organized from outside the region. As a consequence, any profit left the region and the quality of services for visitors deteriorated because most of the lessees were only interested in short term gain. In addition, since the mid 1990's, there has been an ever increasing number of developments occurring in the Šumava NP.

Responsible state authorities, in particular the Ministry of Environment, have responded to regional complaints against the NP and funded various local needs, such as wastewater treatment plants, sewerage systems, road reconstructions, etc. The resulting enhanced funding of municipal and tourism infrastructure is partly revealed by the comparison of municipal budgets in $\mathrm{Ta}$ ble 1 in terms of the annual income per resident in each municipality. The incomes in the 22 municipalities in the NP territory are at least twice that in villages of similar size (categories of 1-100 and 200-500 permanent residents are given for both regions) outside the Šumava NP (http://www.rozpocetobce.cz, http://www.czso.cz). Six villages in the Šumava NP have significantly higher incomes than the others (Table 1). The extremely high incomes of the residents of Modrava came from taxes levied on rich businessman registered there.

Landscape planning, including landscape architecture and spatial planning, has been a weak point and a sub-optimally used tool. Constraints defined in the land use plan for the Great Šumava region, approved by the Czech government as the main plan for the Czech part of the Bohemian Forest, were soon ignored. Currently, local land use plans for many of the villages in the Šumava NP reflect mainly the wishes of various developers, lobbyists, land owners and local decision makers. Unfortunately, some architects submit plans that do not conform to the procedures of the Czech Chamber of Architects and very few of them have been evaluated by SEA. These plans do not stimulate sustainable regional development and utilize the potential of the region. This situation has resulted in controversial developments and local representatives may have been corrupted. Local municipalities must accept responsibility for the maintenance of some developments for decades (e.g. apartment houses in Borová Lada, Nová Pec and Mechov near Srní). Such developments are hardly compatible with sustainable life, largely neglects necessary infrastructures for visitors and fail to provide job opportunities for residents.

Poor spatial planning and crisis in human resources cause serious troubles in business. There are only a few local businesses operated by residents (e.g. a local food store and bakery in Kvilda). Many other stores, restaurants, accommodation and other facilities are leasehold and profits from these leave the Bohemian Forest region.
The socio-demographic situation that currently prevails in the former frontier area may also account for a lack of both local experts and a respect for educated people (cf. the percentage of graduates in Table 1). There are no "Mr. Teacher" or "Mr. Parson", well recognised by their neighbours, as existed in the past. On the contrary, there are unemployed and partly disabled people, who are not motivated to find employment anywhere else than in their village. Although the control of bark-beetles has dominated local "headlines" for decades, most of the salvage logging was done by big companies from other regions, whereas residents are left jobless. Some of those people are easily manipulated and prone to become aggressive, such as the local militia that attacked the eco-activists, who protested against the unjust bark-beetle control measures in the summer of 2011. On the other hand, despite half of the local population consisting of graduates unemployment is close to the mean national unemployment rate but is not as high as in other Czech marginal regions (Table 1).

Expectations of the local people and projects of the municipalities have often exceeded that permitted by the Šmava NP and PLA Authority. Though they should be a partner rather than a leader in regional development, the Authority frequently organised and even funded in the past many regional infrastructural developments and activities in the Czech Bohemian Forest, such as public transport by green buses, winter maintenance of white trails for cross-country skiing and building cycle tracks.

\section{Conclusions}

Unfortunately we have to conclude that, after twenty three years, the Šumava NP presents an apparently intractable Gordian knot of a problem consisting of a tangle of many ideas, misunderstandings, disillusions, lost opportunities and hopes.

Several studies (Těšitel et al. 2003, 2005, 2007; Kušová et al. 2006; Třebický and Čihař 2006; Görner and Čihař 2012) delivered ideas and recommendations, which were mostly ignored. It is hard to say whether they were unrealistic, or the potential recipients were not interested in or not open to new ideas. Some more practical projects were announced, such as the partnership with the successful Bavarian Forest NP (Rall 2008), but not successfully implemented. Also the KIPR project (Landscape integrated regional development plans of the National Park region, i.e. region of the Šumava NP and PLA) were unsuccessfully started in 2009, resuscitated in 2011 and again in 2013. Only a few studies and documents on strategic development have been published so far. Maybe the KIPR project and the database generated by the various projects will help create a new happy land in the National Park region during the course of the next EU financial period (2014-2020). The coming years will reveal whether the KIPR project can initiate a new era in the 
relationship between the Šumava NP and PLA Authority and local people, or this project's partial success will be quickly forgotten like other good projects implemented in previous years, such as, the long-term cooperation of the Authority with local municipalities in maintaining cross-country ski trails; the project "Our Peat Bog", which is a joint project of the Authority, the Volary municipality and its forest company aimed at restoring the excavated peat bog Soumarské Rašeliniště; or the Glass Arch, which is a transboundary project aimed at combining regional cultural history and nature conservation (Eisch 2005).

Unfortunately, more than two decades of experience have shown that these good examples are quickly forgotten, whereas a bitter after taste of misunderstandings, false promises and disappointed hopes prevail. Hopefully this continual state of war between the National Park and local people made someone happy! Maybe yes, maybe not. Who knows? It is clear, however, that a few people increased their own popularity and profits by exploiting this long-term conflict and that there were many more losers than winners.

In America national parks are seen as "one of the best ideas". Thus the hope is that the good ideas that resulted in the establishment of the Šumava NP in the early 1990s, will eventually guide the discussions between local people, visitors, managers and politicians and result in them facing up to their responsibility for safeguarding this amazing island of wild nature. There are several interesting ideas for conserving wild nature and the people friendly management of the Šumava NP in the recent study "An Outline of Economic Impacts of Management Options for Šumava National Park" published by the reputable company EFTEC (Dickie 2014). They used social-economic data from the NP region to evaluate the economic effects of three management scenarios for the Šumava NP: (1) continuation of current management, (2) adoption of the new NP Act that would declassify protected areas and make areas available for development (e.g. ski lift) and (3) increase the size of the wilderness area including associated opportunities for tourism.

\section{Acknowledgments}

This study was supported by the projects OP VK CZ.1.07/2.4.00/17.0130, the CSF grant No. 14-36098G and No. CZ.1.05/1.1.00/02.0073.

\section{REFERENCES}

Čížková P, Svoboda M, Křenová Z (2011) Natural regeneration of acidophilous spruce mountain forests in non-intervention management areas of the Šumava National Park - the first results of the Biomonitoring project. Silva Gabreta 17: 19-35.
Dickie I, Whiteley G, Kindlmann P, Křenová Z, Bláha J (2014) An outline of economic impacts of management options for Šumava National Park. Eur J Environ Sci 4: 5-29.

Eisch S (2005) Glasarche in Waldmeer: Dokumentation einer Reise durch den Bayerische Wald und die Šumava / Skleněná archa v moři lesů: Zpráva o jedné cestě Bavorským lesem a Šumavou. Regensburg: Kartenhaus Kollektive.

Görner T, Čihař M (2012) Indicator system of Czech national parks and biosphere reserves: Some developing trends in the Šumava National Park. Silva Gabreta 18: 49-58.

Hubený P, Čížková P (2013) Věková struktura lesů Šumavy. Silva Gabreta, submitted. (in Czech with English summary)

Janda P, Bače R, Svoboda M, Starý M (2010) Temporal and spatial structure of the mountain Norway spruce forest in the core zone of "Trojmezná" in the Šumava NP. Silva Gabreta 16: 43-59.

Křenová Z, Hruška J (2012) Proper zonation - an essential tool for the future conservation of the Šumava National Park. Eur J Environ Sci 2: 62-72.

Křenová Z, Kiener H (2011) Europe's Wild Heart - Responsibility for Europe. In: Vasilijevic M, Pezold T (eds) Crossing Borders for Nature. European examples of transboundary conservation. Gland: IUCN 42-45.

Křenová Z, Kiener H (2012) Europe’s Wild Heart - still beating? Experiences from a new transboundary wilderness area in the middle of the old continent. Eur J Environ Sci 2: 115-124.

Kušová D, Těšitel J, Matějka K, Bartoš M (2006) Socio-economic conditions in selected biosphere reserves. Silva Gabreta 12: 157-169.

Meyer T, Kiener H, Křenová Z (2009) Wild Heart of Europe. Int J Wilderness 15: 33-40.

Perlín R, Bičík R (2010) Lokální rozvoj na Šumavě: Závěrečná zpráva shrnující výsledky projektu Analýza vývoje NP Šumava za období uplynulých 15 let. Sborníky z výzkumu na Šumavě sešit 4. Vimperk: Správa NP a CHKO Šumava. (in Czech with English summary)

Prach K, Bufková I, Zemek F, Heřman M, Mašková Z (2000) Grassland vegetation in the former military area Dobrá Voda, the Šumava National Park. Silva Gabreta 5: 103-112.

Prach K, Štech M, Beneš J (1996) Druhotné bezlesí - opomíjená složka biodiversity Šumavy. Silva Gabreta 1:243-248. (in Czech with English summary)

Rall H (ed) (2008) The Bavarian Forest NP - an important component of the regional economy: English summary. Grafenau: Bavarian Forest National Park.

Šumava NP Authority (2014) Plán péče o Národní park Šumava pro období 2014-2017 [The National Park Šumava Management Plan for years 2014-2017]. In prep. (in Czech)

Svoboda M (2005) Struktura horského smrkového lesa v oblasti Trojmezné ve vztahu k historickému vývoji a stanovištním podmínkám [Structure of the mountain spruce forest in Trojmezna area related to historical development and site conditions]. Silva Gabreta 11: 42-63. (in Czech with English summary)

Svoboda M (2007) The origin of the forest in the second zone next to Trojmezná old-growth forest is natural: does the management change before it will be cut down? Silva Gabreta 13: 171-187.

Těšitel J, Kušová D, Bartoš M (2003) Tourist's reasons for visiting mountain areas: a case study of the Šumava Mountains. Landscape Research 28: 317-322.

Těšitel J, Kušová D, Matějka K, Bartoš M (2005) Lidé v biosférických rezervacích [People in biosphere reserves]. Institute of System Biology and Ecology, Academy of Siences of the Czech Republic, České Budějovice. (in Czech with English summary) 
Těšitel J, Kušová D, Bartoš M (2007) Šetrný turismus v biosférických rezervacích - nástroj formování sítí spolupráce (prrípadová studie Biosférické rezervace Šumava) [Sound tourism in biosphere reserves - a tool to form a network of cooperation: a case study of the Šumava Biosphere Reserve]. Klagenfurt: Úrad vlády Korutan. (in Czech with English summary)
Třebický V, Čihař M (2006) Analysis of Nature-Based Tourism in the Šumava National Park, Czech Republic: 1997-2004. In: Siegrist D, Clivaz C, Hunziker M, Iten S (eds): Exploring the Nature of Management. Proceedings of the Third International Conference on Monitoring and Management of Visitor Flows in Recreational and Protected Areas. Rapperswil, pp. 228-232. 